\title{
An In-House Method for Molecular Monitoring of BCR-ABL
}

\author{
BCR-ABL Moleküler Takibi İçin Optimize Edilmiş Manuel Bir Yöntem
}

\author{
Hakkı Ogün Sercan, Ilgın Öztürk, Ceyda Çalışkan, Melek Pehlivan, Zeynep Sercan
}

Dokuz Eylül University, School of Medicine, Department of Medical Biology and Genetics, İzmir, Turkey

\begin{abstract}
Objective: At present, there are a limited number of facilities in Turkey that can provide reliable real-time quantitative (RQ)-PCR BCR-ABL results. The present study aimed to test a cost-effective, in-house method of BCR-ABL quantification, including verification of the method by RQ-PCR validation tests.

Material and Methods: BCR-ABL and ABL target sequences were cloned into pJET1.2 vectors, from which calibrators were prepared and used as templates in RQ-PCR reactions to generate standard curves. Dilutions of $\mathrm{K562}$ cells (representing an in vitro simulation of BCR-ABL transcript reduction) were analyzed.

Results: Standard curves were generated from calibrators. These curves were then used to calculate the BCR-ABL and ABL copy numbers; in which linear BCR-ABL results were obtained. Repetitive experiments showed that our methodology was able to detect 1 BCR-ABL positive cell from amnong $1 \times 10^{5}$ cells.

Conclusion: The method described herein is suitable for implementation with any RQ-PCR instrument and/or kit for quantify BCR-ABL transcripts.
\end{abstract}

Key Words: Chronic myeloid leukemia, BCR-ABL, Real-time PCR, Molecular response

Özet

Amaç: Türkiye'de BCR-ABL gerçek zamanlı kantitatif polimeraz zincir tepkimesi ile BCR-ABL düzey tayini yapabilen merkezlerin sayısı, ihtiyacın altında kalmaktadır. BCR-ABL kantitasyonu için laboratuarımızda geliştirmiş olduğumuz yöntem temel alınarak, (PZT) ile kantitasyonun basamakları, iç kontrolleri ve geçerlilik testleri anlatılmıştır.

Gereç ve Yöntemler: BCR-ABL ve ABL hedef dizileri pJET1.2 vektörlerine klonlandıktan sonra kalibratörler hazırlanmış ve gerçek zamanlı PZT tepkimelerinde kalıp olarak kullanılarak standart eğriler çizilmiştir. Bu standart eğriler kullanılarak K562 hücre dilüsyonlarının analizi yapılmıştır.

Bulgular: Önceden elde edilen standart eğriler kullanılarak BCR-ABL ve ABL kopya sayıları hesaplanmış; lineer sonuçlar elde edilmiştir. Tekrarlayan deneylerle yöntem duyarlıı̆ının $1 \times 10^{5}$ hücrede bir BCR-ABL pozitif hücreyi saptayacak düzeyde olduğu gösterilmiştir.

Sonuç: Bu makalede tarif elden protokollerin geçerliliği/güvenirliliği gösterilmiştir. Kullanılan yaklaşım, BCR-ABL kantitasyonunun hedefleyen diğer gerçek zamanlı PZT kit ve crhazlarma da uyarlanabilmektedir.

Anahtar Sözcükler: Kronik miyeloid lösemi, BCR-ABL, Gerçek zamanlı PCR, Moleküler yanıt

Address for Correspondence: Hakkı Ogun SERCAN, M.D.,

Dokuz Eylül Üniversitesi Tıp Fakültesi, Tıbbi Biyoloji ve Genetik Anabilim Dalı İzmir, Turkey

Phone: +90 2324124623 E-mail: ogun.sercan@deu.edu.tr 


\section{Introduction}

Chronic myeloid leukemia (CML) is a clonal myeloproliferative disorder of hematopoietic stem cell origin. The Philadelphia chromosome (Ph) - $\operatorname{der}(22) \mathrm{t}(9 ; 22)$ (q34;q11) —is the hallmark of CML, and is formed via reciprocal translocation between the long arms of chromosomes 9 and 22. The translocation results in the juxtaposition of the 5' end of the BCR gene and the 3' end of the $\mathrm{ABL}$ gene, generating a $\mathrm{BCR}-\mathrm{ABL}$ chimeric oncogene with aberrant kinase activity. The introduction of imatinib mesylate-a small-molecule competitive inhibitor of the BCR-ABL kinase-in 1998 substantially changed the management of CML [1]. Decades of research on CML has led to very effective molecularly targeted therapies.

Since the late 1980's the percentage of Ph-positive cells in bone marrow based on cytogenetic analysis has been the gold standard for monitoring the response to therapy $[1,2,6]$. Prior to the use of tyrosine kinase inhibitors for the treatment of CML a molecular response was rarely achieved and it was therefore not feasible to routinely monitor BCR-ABL transcript levels, with the exception of patients that underwent bone marrow transplantation [1-6]. Currently, tyrosine kinase inhibitors are the preferred first-line therapy for CML and based on IRIS trial data a 3-log reduction in BCR-ABL transcript levels after 12 months correlates with progression-free survival [1-6].

Molecular monitoring of CML patients has become clinically very important. Developments in real-time quantitative (RQ)-PCR technology as well as real-time chemistry have enabled routine, high throughput detection of BCR-ABL transcript levels. In turn, there has been an expected increase in the number of centers that provide RQ-PCR results for BCR-ABL mRNA. The rapid increase of these centers revealed that there were significant variations between individual laboratories in reporting RQ-PCR data [5-12]. The International Scale (IS) has been adopted for reporting BCR-ABL values based on the application of laboratory-specific conversion factors that are derived using patient samples [6-12].

Presently, few hospitals in Turkey can provide reliable RQ-PCR BCR-ABL results. Effective implementation of RQ-PCR requires knowledge of reaction kinetics and instrumentation, as well as extensive experience. Lack of experienced personnel could lead to over-dependence on the technical assistance of RQ-PCR kit manufacturers, which in turn may prove to be less than satisfactory. Herein we describe a cost-effective, in-house method developed in our laboratory, and detailed descriptions of validation tests and an in vitro simulation of transcript reduction, all which could be adapted to any RQ-PCR methodology chosen for detecting BCR-ABL transcript levels.

\section{Materials and Methods}

The study protocol was approved by the Dokuz Eylül University Clinic \& Laboratory Reseach Ethics Committee.

\section{Primers and probes}

RQ-PCR results for BCR-ABL are usually presented as a ratio of the $B C R-A B L$ transcript level and the reference control gene transcript level. Normalization to a reference gene compensates for variation in the efficiency of the reaction and RNA quality between samples. The most widely used reference control gene in BCR-ABL monitoring is the wild-type ABL gene $[9,13]$.

PCR primers used for BCR-ABL facilitate amplification of $\mathrm{b} 2 \mathrm{a} 2$ and $\mathrm{b} 3 \mathrm{a} 2$ transcripts, which comprise the BCR exon b2/b3 and ABL exon 2 (primers synthesized by Metabion $\mathrm{GmbH}$, Martinsried, Germany). A dual-labeled (5' 6-FAM and 3' TAMRA as quencher) hydrolysis probe (TaqMan Probe, Roche Diagnostics, Mannheim, Germany) was used for real-time detection of product accumulation during each cycle. The primer and probe sequences are shown in Figure 1. We used the wild-type ABL gene as the reference gene. The primers used most widely for quantification of ABL also amplify the BCR-ABL fusion transcript $[9,12,13]$. It has been reported, and also observed by us, that this may cause a bias in results, especially when a large

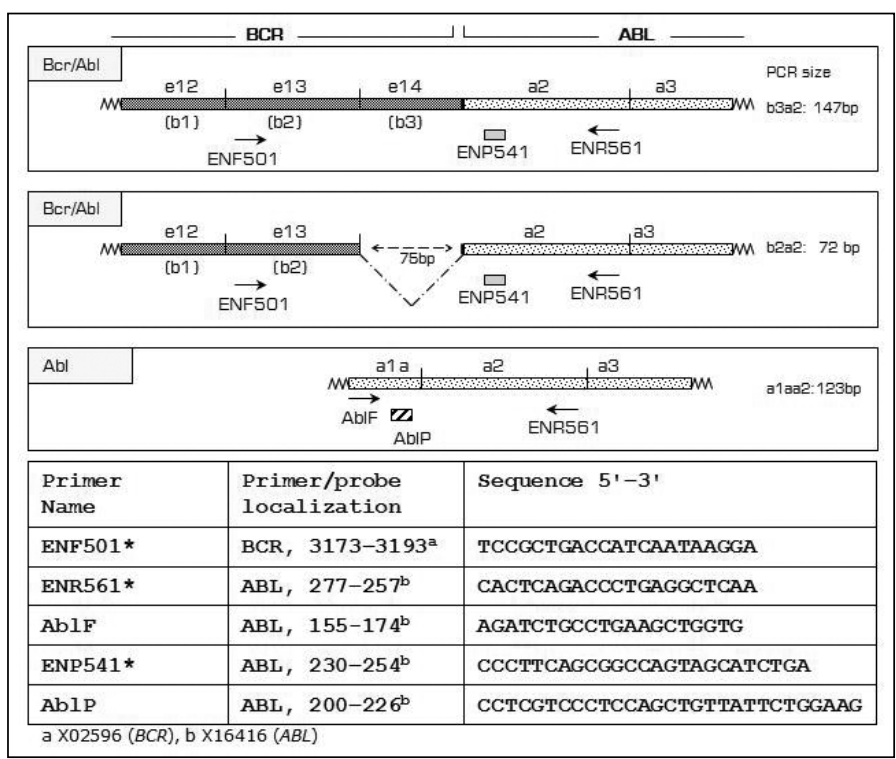

Figure 1: BCR-ABL fusion gene primer/probe sequences and locations (*sequences were obtained from reference 18). 
quantity of BCR-ABL is present in the sample $[9,12,13]$. The primer and hydrolysis probe sequences we used for ABL (Figure 1) were determined to hybridize only to wildtype ABL and not BCR-ABL.

\section{Cell lines}

K562 is a BCR-ABL-positive cell line derived from a CML patient in erythroid blast crisis. RS4;11 is a BCRABL-negative cell line derived from an acute myelocytic leukemia (AML) patient and was used as a BCR-ABL-negative cell line control. Both cell lines were purchased from DSMZ (Deutsche Sammlung von Mikroorganismen und Zellkulturen GmbH, Germany) and grown in RPMI-1640 medium supplemented with 15\% FBS and 1\% L-glutamine in a $5 \% \mathrm{CO}_{2}$-saturated incubator at $37^{\circ} \mathrm{C}$.

\section{Standard curves and copy numbers}

Calibrators necessary to create the standard curves for product quantity were generated by cloning the target DNA into plasmids, followed by copy number determination and preparation of serial dilutions. RNA or DNA standards may be used for RQ-PCR, but DNA standards are reported to have superior stability. The Europe Against Cancer (EAC) Programme established standardized protocols for fusion transcript quantification and concluded that DNA plasmids were appropriate for constructing standard curves, whereas RNA and cDNA did not provide the stability of plasmids $[10,13]$.

Total RNA was extracted from K562 cells (Macherey Nagel-Nucleospin RNAII, Düren, Germany). To avoid genomic DNA contamination RNA samples were treated with RNase-free DNase I, according to the manufacturer's instructions. cDNA was synthesized using a First Strand cDNA Synthesis Kit (MBI-Fermentas K1611, St. LeonRot, Germany), $2 \mu \mathrm{g}$ of total RNA, and random primers, according to the manufacturer's instructions. cDNA $(5 \mu \mathrm{L})$ was used as the template in a conventional PCR reaction performed with primers ENF501 and ENR561 (Figure 1) to amplify the target BCR-ABL region. The PCR product was cloned into a pJET1.2 vector, in accordance with the manufacturer's instructions (CloneJET PCR Cloning Kit, MBI Fermentas, St. Leon-Rot, Germany).

Following colony selection, plasmid DNA was isolated (NucleoBond ${ }^{\circledR}$ PC20 Macherey Nagel, Düren, Germany) and analyzed spectrophotometrically. Similar procedures were performed for the ABL gene. Primers AblF and ENR561 (Figure 1) were used to amplify the ABL sequence in a conventional PCR reaction, in which cDNA from K562 cells were used as template. The amplification product was cloned into a pJETl.2 vector, followed by colony selection and plasmid analysis.

To prepare the calibrators the plasmid copy number $\mu \mathrm{L}^{-1}$ volume was determined using the following equation (in brief, the molecular weight of the DNA template can be determined by multiplying the number of base pairs (bp) by the weight of $1 \mathrm{~mol}$ of a bp estimated to be $650 \mathrm{~g}$; using $6.022 \times 10^{23}$ [Avogadro's number] molecules $\mathrm{mol}^{-1}$, the number of molecules of the template can be calculated by first converting to $\mathrm{ng}$ [multiplying $1 \times 10^{9}$ ] and then multiplying by the quantity of template) [14]:

copy number $\mu \mathrm{L}^{-1}=$ [quantity $\left(\mathrm{ng} \mu \mathrm{L}^{-1}\right) \times(6.022 \mathrm{x}$ $\left.\left.10^{23}\right)\right] /\left[\right.$ plasmid length (bp) x $1.10^{9} \times 650$ ]

Calibrators containing $10^{2}, 10^{3}, 10^{4}, 10^{5}$, and $10^{6}$ gene copies were prepared for both the BCR-ABL and ABL genes. These calibrators were used as templates in RQ-PCR reactions to generate standard curves. RQ-PCR was carried out using a LightCycler 2.0 (Roche Diagnostics, Mannheim, Germany) instrument and LightCycler TaqMan Master Kit (Roche Diagnostics, 0453528001, Mannheim, Germany). Reactions were performed in a $20-\mu \mathrm{L}$ volume with 10 pmol of each primer and probe. The same thermal profile was optimized for BCR-ABL and ABL: pre-incubation for 10 min at $95^{\circ} \mathrm{C}$, followed by 45 amplification cycles of denaturation at $95^{\circ} \mathrm{C}$ for $10 \mathrm{~s}$, primer annealing at $58^{\circ} \mathrm{C}$ for $40 \mathrm{~s}$, and primer extension at $72{ }^{\circ} \mathrm{C}$ for $2 \mathrm{~s}$. $\mathrm{dH}_{2} \mathrm{O}$ was included as a no template control. Fluorescence was measured during the $72-^{\circ} \mathrm{C}$ segment in each cycle. Data were analyzed using LightCycler v.4.0.0.23 software (Roche Diagnostics, Mannheim, Germany). Standard curves for both BCR-ABL and ABL were generated and saved for further use (Figure 2). All samples in glass capillaries were subsequently run in 2\% agarose gel electrophoresis to check for size and non-specific amplifications. All data were derived from independent experiments performed in triplicate.

\section{Serial dilutions of $\mathrm{K562}$ cells}

Dilutions of K562 cells were prepared in the background of the BCR-ABL-negative RS4;1 1 cell line. Mixtures of BCR-ABL-positive K562 and BCR-ABL-negative RS4;11 cells were prepared, and the total cell number was always $10^{5}$. The sample mixtures of K562/ RS4;11 cells were prepared so that they contained $10,000,1000,100,10,1$, or $0 \mathrm{~K} 562$ cells. These samples represent in vitro simulation of BCR-ABL transcript reduction in a CML patient undergoing therapy. Total RNA isolation and CDNA preparation were performed as described in the previous section. The cDNA was used as a template for determining the 

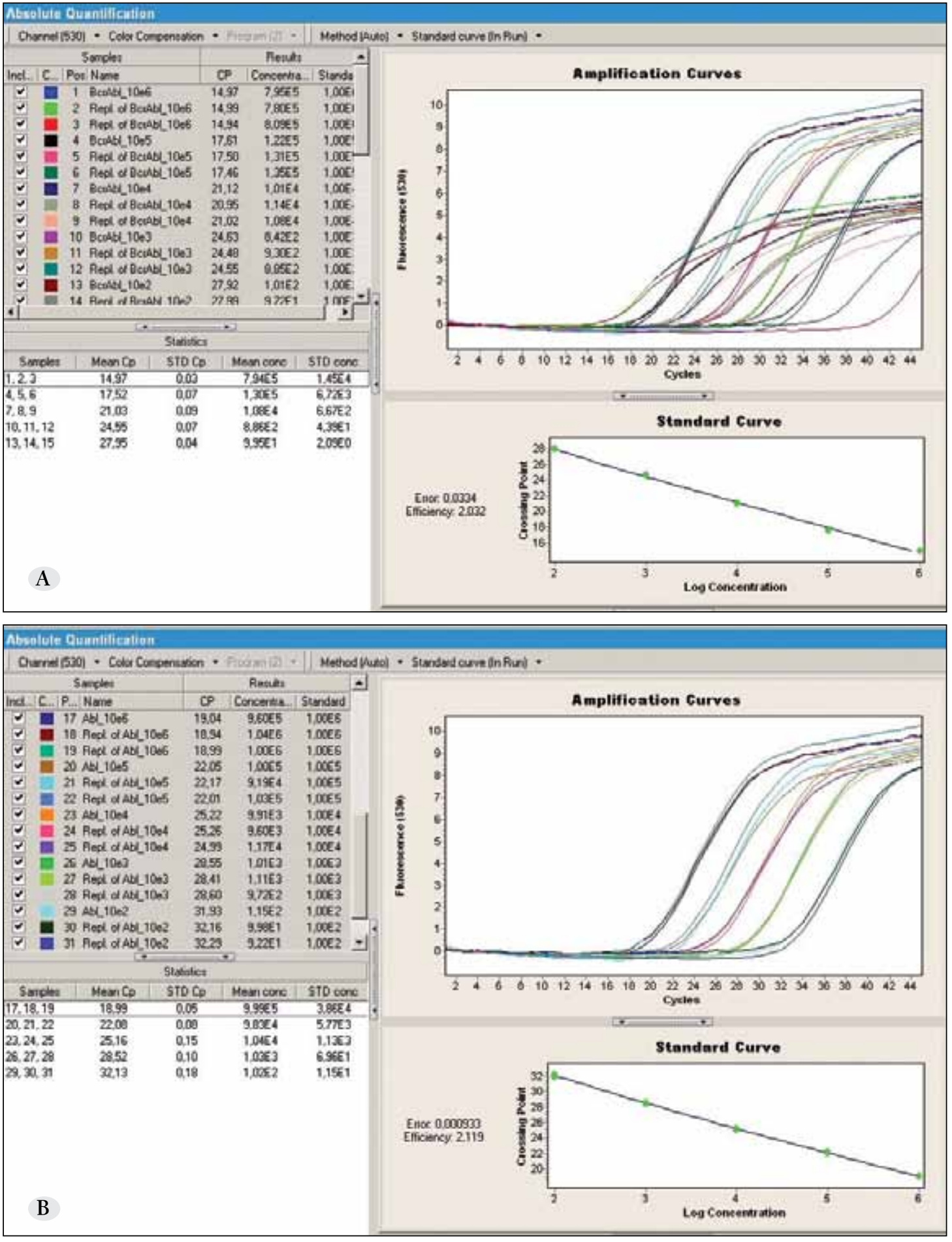

Figure 2: A. Standard curve, $C p$ values, and amplification curves for BCR-ABL during RQ-PCR. B. Standard curve, $C p$ values, and amplification curves for ABL during RQ-PCR
BCR-ABL transcript levels in quantitative PCR reactions. RQ-PCR was performed in independent triplicate sets, as described in the previous section.

\section{Results and Interpretation}

RQ-PCR results for the K562/RS4;11 sample mixtures were analyzed using the previously determined standard curves. These standard curves were used to calculate the quantity of BCR-ABL and ABL transcript (copy numbers) in the samples. Change/reduction in the BCR-ABL transcript level was expressed as the ratio of BCR-ABL:ABL (Figure 3). As expected, amplification product was not observed in the $\mathrm{dH}_{2} \mathrm{O}$-negative controls, whereas amplification was evident in the $10^{6}$ copies $\mu \mathrm{L}^{-1}$ BCR-ABL-pos- 


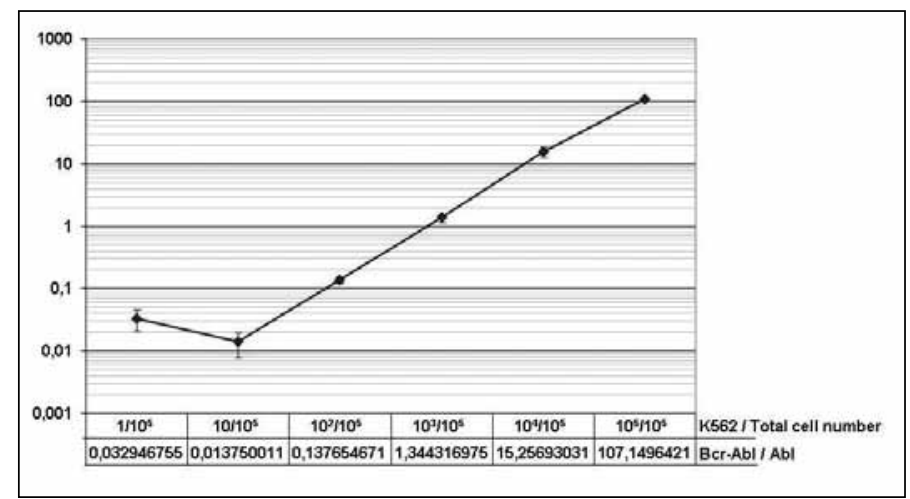

Figure 3: Dilutions of K562 cells were prepared in the background of the BCR-ABL-negative RS4;11 cell line and were subjected to RQ-PCR. Previously determined standard curves were used to calculate the BCR-ABL and ABL transcript copy numbers, and the results are plotted on a logarithmic scale (Y-axis). Change/reduction in the BCR-ABL transcript level is expressed as the ratio of BCR-ABL / ABL.

itive control sample. From the sample mixtures of K562/ RS4; 11 cells only 1 sample that contained $10^{5}$ RS4;11 cells (no K562 cells) was observed to be negative for the BCRABL transcript in repetitive experiments. The Cp value for ABL in this sample was very similar to other K562/RS4;11 mixtures, each of which contained $10^{5}$ cells, indicating that the result for BCR-ABL was indeed a true negative. All other sample mixtures were positive for the BCR-ABL transcript, albeit in decreasing order. Repeated experimentation showed that our methodology was able to detect 1 BCR-ABL-positive cell from among $10^{5}$ cells, which is the level of sensitivity generally accepted for BCR-ABL monitoring $[15,16]$. Analysis of the samples that contained varying quantities of BCR-ABL-positive cells is shown in Figure 3.

\section{Discussion}

RQ-PCR is a technically demanding, yet very powerful tool. The exquisite sensitivity of the assay is also its weakness. It is essential that extreme care be taken to avoid false-positive results due to cross-contamination and carry-over of RNA/DNA from a previous amplification. The calibrators themselves are the greatest threat of contamination, as they are cloned DNA containing DNA target regions. Their preparation, storage, and handling should not be performed in the same laboratory in which patient samples are processed. All equipment, including pipette sets, kits, reagents, paper, pens, workbooks, and lab coats should be dedicated for use only in that particular laboratory. It is of great importance that the rules of good labo- ratory practice be followed when setting up PCR assays and during post-PCR processing of samples. Though not addressed herein, there are excellent reviews of recommended pre-PCR procedures in the literature, including handling of blood samples, RNA extraction, cDNA synthesis, and reverse transcription [8-10,17]. $\mathrm{A} \mathrm{dH}_{2} \mathrm{O}$-negative control (BCR-ABL negative cells), along with low and high positive controls should be included in each RQ-PCR run to monitor assay performance. Any changes in technique, protocol, or instrument should be accompanied by a thorough evaluation. Standard curves should be generated after opening a new real-time kit or when a new batch of primer/probe is diluted.

Over the past five years significant advances leading to more wide-spread adaptation of RQ-PCR for BCR-ABL have occurred. Implementation of the IS has improved the comparability of results between laboratories, and recently accredited reference reagents for BCR-ABL quantification have been developed [7]. It is essential that more diagnostic centers in Turkey qualify to report BCR-ABL results according to the IS. In essence, the procedure involves assignment of a laboratory-specific conversion factor (CF) to convert BCR-ABL measurements to the IS [15]. Log BCR-ABL values of the same sample set are compared to reference and local laboratories via linear regression [17]. The results are considered linear when the correlation coefficient of any 2 laboratories is $>0.98$ [17]. The prerequisite for the procedure is that all in-house validation tests be performed and confirmed prior to application. In this context, the present study aimed to describe a costeffective, in house method for BCR-ABL quantification and to illustrate an example for RQ-PCR validation testing, as well as to provide a description of DNA plasmids that may be implemented into any RQ-PCR methodology to quantify BCR-ABL transcripts. The primary advantage of the presented methodology over widely used commercial kits-in addition to being cost effective-is that once optimized and validated, both absolute and relative quantification can be performed, whereas most commercial kits are restricted to providing relative quantification results. In conclusion, the methodology described herein is suitable for implementation into any RQ-PCR instrument and/ or kit for quantifying BCR-ABL transcripts.

\section{Conflict of Interest Statement}

The authors of this paper have no conflicts of interest, including specific financial interests, relationships, and/ or affiliations relevant to the subject matter or materials included. 


\section{References}

1. Goldman JM. Chronic myeloid leukemia: A historical perspective. Semin Hematol 2010;47: 302-311.

2. Hughes T, Branford S. Molecular monitoring of BCR-ABL as a guide to clinical management in chronic myeloid leukaemia. Blood Rev 2006;20: 29-41.

3. Goldman J. Monitoring minimal residual disease in BCRABL-positive chronic myeloid leukemia in the imatinib era. Curr Opin Hematol 2005;12: 33-39.

4. Hughes TP, Kaeda J, Branford S, Rudzki Z, Hochhaus A, Hensley ML, Gathmann I, Bolton AE, van Hoomissen IC, Goldman JM, Radich JP; International Randomised Study of Interferon versus STI571 (IRIS) Study Group. Frequency of major molecular responses to imatinib or interferon alfa plus cytarabine in newly diagnosed chronic myeloid leukemia. N Engl J Med 2003;349: 1423-1432.

5. Hughes TP, Branford S. Monitoring disease response to tyrosine kinase inhibitor therapy in CML. Hematology Am Soc Hematol Educ Program 2009;477-487.

6. Hughes T. ABL kinase inhibitor therapy for CML: Baseline assessments and response monitoring. Hematology Am Soc Hematol Educ Program 2006;211-218.

7. White HE, Matejtschuk P, Rigsby P, Gabert J, Lin F, Lynn Wang Y, Branford S, Müller MC, Beaufils N, Beillard E, Colomer D, Dvorakova D, Ehrencrona H, Goh HG, El Housni H, Jones D, Kairisto V, Kamel-Reid S, Kim DW, Langabeer S, Ma ES, Press RD, Romeo G, Wang L, Zoi K, Hughes T, Saglio G, Hochhaus A, Goldman JM, Metcalfe P, Cross NC. Establishment of the first World Health Organization International Genetic Reference Panel for quantitation of BCR-ABL mRNA. Blood 2010;116: el11117.

8. Hughes T, Deininger M, Hochhaus A, Branford S, Radich J, Kaeda J, Baccarani M, Cortes J, Cross NC, Druker BJ, Gabert J, Grimwade D, Hehlmann R, Kamel-Reid S, Lipton JH, Longtine J, Martinelli G, Saglio G, Soverini S, Stock W, Goldman JM. Monitoring CML patients responding to treatment with tyrosine kinase inhibitors: review and recommendations for harmonizing current methodology for detecting BCR-ABL transcripts and kinase domain mutations and for expressing results. Blood 2006;108: 28-37

9. Cross NC. Standardisation of molecular monitoring for chronic myeloid leukaemia. Best Pract Res Clin Haematol 2009;22: 355-365.

10. Branford S, Cross NC, Hochhaus A, Radich J, Saglio G, Kaeda J, Goldman J, Hughes T. Rationale for the recommendations for harmonizing current methodology for detecting BCRABL transcripts in patients with chronic myeloid leukaemia. Leukemia 2006;20:1925-1930.
11. Branford S, Fletcher L, Cross NC, Müller MC, Hochhaus A, Kim DW, Radich JP, Saglio G, Pane F, Kamel-Reid S, Wang YL, Press RD, Lynch K, Rudzki Z, Goldman JM, Hughes T. Desirable performance characteristics for BCR-ABL measurement on an international reporting scale to allow consistent interpretation of individual patient response and comparison of response rates between clinical trials. Blood 2008;112: 3330-3338.

12. Cross NC, Hughes TP, Hochhaus A, Goldman JM. International standardisation of quantitative real-time RT-PCR for BCR-ABL. Leuk Res 2008;32: 505-506.

13. Beillard E, Pallisgaard N, van der Velden VH, Bi W, Dee R, van der Schoot E, Delabesse E, Macintyre E, Gottardi E, Saglio G, Watzinger F, Lion T, van Dongen JJ, Hokland P, Gabert J. Evaluation of candidate control genes for diagnosis and residual disease detection in leukemic patients using 'real-time' quantitative reverse-transcriptase polymerase chain reaction (RQ-PCR) - a Europe against cancer program. Leukemia 2003; 17: 2474-2486.

14. URI Genomics \& Sequencing Center, Calculator for determining the number of copies of a template http://www. uri.edu/research/gsc/resources/cndna.html.

15. Cortes J, Talpaz M, O'Brien S, Jones D, Luthra R, Shan J, Giles F, Faderl S, Verstovsek S, Garcia-Manero G, Rios MB, Kantarjian H. Molecular responses in patients with chronic myelogenous leukemia in chronic phase treated with imatinib mesylate. Clin Cancer Res 2005;11: 3425-3432.

16. Luthra R, Sanchez-Vega B, Medeiros LJ. TaqMan RT-PCR assay coupled with capillary electrophoresis for quantification and identification of bcr-abl transcript type. Mod Pathol 2004;17: 96-103.

17. Müller MC, Cross NC, Erben P, Schenk T, Hanfstein B, Ernst T, Hehlmann R, Branford S, Saglio G, Hochhaus A. Harmonization of molecular monitoring of CML therapy in Europe. Leukemia 2009;23: 1957-1963

18. Gabert J, Beillard E, van der Velden VH, Bi W, Grimwade D, Pallisgaard N, Barbany G, Cazzaniga G, Cayuela JM, Cavé H, Pane F, Aerts JL, De Micheli D, Thirion X, Pradel V, González M, Viehmann S, Malec M, Saglio G, van Dongen JJ. Standardization and quality control studies of 'real-time' quantitative reverse transcriptase polymerase chain reaction of fusion gene transcripts for residual disease detection in leukemia - a Europe Against Cancer program. Leukemia 2003;17: 2318-2357 